\title{
THE EFFECT OF WHATSAPP APPLICATION ON THE STUDENTS' EARLY READING ABILITY AT GRADE I ELEMENTARY SCHOOL
}

\author{
Muhardila Fauziah $^{1}$, Tatat Hartati ${ }^{2}$, Vismaia S. Damaianti ${ }^{3}$, Yeni Sulaeman ${ }^{4}$ \\ ${ }^{1}$ Universitas PGRI Yogyakarta, Yogyakarta, Indonesia \\ ${ }^{2,3,4}$ Universitas Pendidikan Indonesia, Bandung, Indonesia \\ 'dfauziah1988@gmail.com
}

\section{PENGARUH PENGAJARAN APLIKASI WHATSAPP TERHADAP KEMAMPUAN MEMBACA PERMULAAN SISWA KELAS I SD}

\begin{tabular}{|c|c|}
\hline ARTICLE HISTORY & ABSTRACT \\
\hline $\begin{array}{l}\text { Submitted: } \\
\text { 04 Januari } 2021 \\
\text { 04 }{ }^{\text {th }} \text { January } 2021\end{array}$ & $\begin{array}{l}\text { Abstract: Early in } 2020 \text {, Pandemic Covid-19 spread in almost all regions of Indonesia which } \\
\text { resulted in changing in the teaching process. Teaching was carried out by using various digital } \\
\text { applications, one of which was WhatsApp application. The purpose of this study was to } \\
\text { describe the teaching through WhatsApp application as a learning resource and tool, and to } \\
\text { find out the effect of WhatsApp on the students' reading ability at grade } 1 \text {. The method in this } \\
\text { study was a quantitative experimental research with a questionnaire, interviews, and } \\
\text { observations as the instruments. The subjects of this study were grade I students who were } \\
\text { registered in elementary schools and participating in teaching with WhatsApp. The results of } \\
\text { the study illustrated that WhatsApp application used by the teacher was ineffective as a } \\
\text { medium and learning tool for grade } 1 \text { elementary school students. The data revealed that } 70 \% \\
\text { of parents stated that their children were not yet able to read, } 12 \% \text { of parents stated that their } \\
\text { children were not able to recognize and pronounce words correctly. In conclusion, WhatsApp } \\
\text { had no effect on students' initial reading abilitys during the Covid-19 pandemic as the result of } \\
\text { the hypothesis testing indicated that the probability value (significance) was } 0.000 ; \text { thus, Ho } \\
\text { was rejected. Using WhatsApp application as a medium for early reading was not } \\
\text { recommended. }\end{array}$ \\
\hline
\end{tabular}

Accepted:

23 Maret 2021

$23^{\text {nd }}$ March 2021

Published:

14 April 2021

$14^{\text {th }}$ April 2021

Keywords: Whatsapp Application, Early Reading, Grade I Students

Abstrak: Awal tahun 2020 pandemic covid-19 menyebar di hampir seluruh wilayah Indonesia. Mengakibatkan berubahnya proses pengajaran di bidang pendidikan. Pengajaran dilaksanakan mengunakan berbagai aplikasi digital salah satunya aplikasi Whatsapp (WA) Tujuan penelitian ini mengambarkan pengajaran dengan mengunakan aplikasi Whatsapp (WA) sebagai sumber dan alat pembelajaran, dan mengetahui pengaruh aplikasi Whatsapp terhadap kemampuan membaca siswa kelas 1. Metode yang digunakan pada penelitian ini adalah metode penelitian eksperimen kuantitatif dengan intrumen angket, wawancara, serta pengamatan yang dilakukan pada siswa kelas 1 yang telah terdaftar di sekolah dasar yang mengikuti pengajaran dengan aplikasi Whatsapp. Hasil penelitian mengambarkan bahwa aplikasi whatsapp yang digunakan guru sangat tidak efektif sebagai media dan alat pembelajaran bagi siswa kelas 1 sekolah dasar. Pengaruh dari pengunaan media whatsapp sebagai media dan alat belajar yang digunakan pada masa pandemic ini $70 \%$ orang tua menyatakan bahwa anaknya belum mampu membaca, $12 \%$ orang tua menyatakan anaknya belum mampu mengenal melafalkan kata dengan benar dan tepat. Simpulanya aplikasi whatsapp tidak memberi pengaruh terhadap kemampuan membaca permulaan siswa selama pandemic covid-19 sebagaimana hasil perhitungan uji hipotesis menunjukkan bahwa nilai probabilitas (signifikasi) adalah 0.000. Karena nilai signifikansi $0.000<\alpha=0.05$, maka Ho ditolak. Penggunaan aplikasi Whatsaap sebagai media untuk membaca permulaan tidak disarankan

Kata Kunci: aplikasi Whatsapp, Membaca Permulaan, Siswa Kelas 1

\section{CITATION}

Fauziah, M., Hartati, T., Damaianti, D. S., \& Sulaeman, Y. (2021). The Effect of Whatsapp Application on the Students' Early Reading Ability at Grade I Elementary School. Primary: Jurnal Pendidikan Guru Sekolah Dasar, 10 (2), 346-352. DOI: 


\section{PENDAHULUAN}

Pandemi yang mendunia mengakibatkan seluruh Negara di dunia mengalami perubahan system disegala bidang, salah satunya pada bidang pendidikan. Di Negara Indonesia sendiri hampir seluruh wilayah kota/kabupaten berdampak covid-19. Indonesia sebagai Negara yang kaya dengan sosial budaya, silahturahmi menjadi suatu kebiasaan dan karakter bangsa diubah dengan beberapa aturan pemerintah untuk meredam perkembangan virus covid-19 (Setiati \& Azwar, 2020). Kegiatan pembelajaran yang mulai dikembalikan dengan budaya tradisional harus mengunakan media digital seperti penggunaan aplikasi whatsapp, zoom meeting, google meet, dan lainnya.

Fenomena yang terjadi saat sekarang ini masih sangat panjang, di mana pemerintahaan di Indonesia telah beberapa kali melakukan lockdown, PSBB (pembatasan sosial berskala besar), dan PKM (pembatasan kegiatan masyarakat). Sehingga semenjak bulan Februari 2020 pemerintah telah beberapa kali mengundur masuk dan dilaksanakannya proses pembelajaran tatap muka. Namun sekarang ini Januari 2021 proses pembelajaran masih dilakukan secara daring. Dilihat dari fenomena tersebut penulis melakukan observasi serta pengamatan kepada siswa sekolah dasar khususnya kelas 1. Pengajaran yang biasanya dilakukan disekolah mengunakan beberapa strategi, teknik, dan metode pembelajaran yang menarik dan menyenangkan bagi siswa bahkan perlakukan khusus diberikan oleh guru untuk memenuhi tujuan pembelajaran.

Menurut (Dewi et al., 2021) pemilihan model pembelajaran dipengaruhi oleh sifat dari materi yang akan diajarkan juga dipengaruhi oleh tujuan yang akan dicapai siswa. Sejalan dengan pendapat (Fauziah, 2019) yang menyatakan bahwa pengunaan model atau metode memiliki pengaruh terhadap kemampuan membaca siswa. Jadi kesimpulan dari dua pendapat di atas mengungkapkan bahwa model dan metode member pengaruh terhadap tujuan pembelajaran.

Hasil observasi yang penulis lakukan pada anak yang berusia 6-8 tahun yang berada di lingkungan tempat tinggal penulis yang duduk dibangku kelas 1 atau 2 menyatakan bahwa mereka selama pandemi covid-19 tidak belajar. Kemampuan membaca siswa dapat dikategorikan cukup. Selanjutnya pendapat orang tua bahwa mereka sekarang ini tidak hanya berpikir tentang bagaimana mendapatkan uang untuk keluarga tetapi mereka harus berperan lebih dari biasanya dirumah yaitu sebagai seorang guru. Beberapa orang tua merasa sebaiknya anaknya tidak masuk sekolah pada tahun ajaran 2020/2021 dikarenakan orang tua tetap mendampingi anaknya belajar, karena seharusnya mereka menyerahkan anak-anaknya untuk belajar di sekolah dan menjemput anak-anak mereka saat siang. Melihat proses pembelajaran yang dilakukan melalui daring maka penulis ingin mengetahui apakah dengan menggunakan aplikasi whatsapp pada proses pembelajaran membaca permulaan pada siswa kelas 1 sekolah dasar dapat meningkatkan kemampuan membaca permulaannya.

Berdasarkan hasil observasi di atas penulis melakukan penelitian tentang pengaruh aplikasi whatsapp terhadap kemampuan membaca permulaan siswa kelas 1 sekolah dasar karena dilatar belakangi dari upaya guru menyampaikan pengajaran untuk siswa kelas 1 melalui aplikasi whatsapp dan mengukur kemampuan membaca permulaan siswa kelas 1 .

\section{KAJIAN TEORI}

Media sosial merupakan media untuk mempermudah komunikasi baik antar individu maupun kelompok untuk berbagi informasi maupun pengetahuan melalui media online/daring dengan memanfaatkan teknologi 
internet (Widhiyasari et al., 2019). Menurut (Rifki, 2017) WhatsApp adalah aplikasi media sosial yang dapat melakukan text/voice chat, photo sending, video sending, document sending dan location sending. Sehingga dengan media sosial WhatsApp ini dapat mengkontruksi sebuah budaya pada generasi melek teknologi juga lebih tepat digunakan sebagai komunikasi yang bersifat personal maupun group yang dapat menjadi sarana untuk menjaga hubungan dengan orang lain serta sebagai sumber informasi. Menurut (Elianur, 2017; Syarifhidayat \& Hendra, 2018) WhatsApp adalah aplikasi pesan untuk smartphone dengan desain mirip BlackBerry Messenger. WhatsApp Messenger merupakan aplikasi lintas platform yang memungkinkan kita bertukar pesan tanpa biaya SMS. Karena WhatsApp Messenger menggunakan paket data internet yang sama untuk e-mail, browsing web, dan lain-lain. Aplikasi WhatsApp Messenger menggunakan koneksi $3 \mathrm{G}$ atau Wifi untuk komunikasi data. Dengan menggunakan WhatsApp, kita dapat melakukan obrilan online, berbagi file, bertukar photo dan lain lain. Menurut (Suryadi et al., 2018; Widhiyasari et al., 2019) WA merupakan sebuah aplikasi seluler lintas platform sehingga pengunaan aplikasi ini gratis dan bisa mengirim tidak hanya dalam bentuk teks saja melainkan juga bisa dalam bentuk gambar, pesan video dan audio dalam jumlah tidak terbatas. Selain itu aplikasi WA menjadi aplikasi pesan instan untuk smartphone, kegunaan WA hampir sama dengan SMS, sehingga WhatsApp tidak menggunakan pulsa melainkan data internet. Untuk itu tidak perlu khawatir dengan jumlah karakter atau informasi yang akan dikirim serta tidak ada limit selama data internet cukup.

Membaca merupakan proses pengajaran yang kompleks dengan melibatkan berbagai keterampilan pada pelaksanaan dan tujuannya. Selanjutnya membaca permulaan mengaju pada proses recoding dan decoding serta proses yang bersifat fisik dan psikologis
(Chandra Chandra et al., 2018; Gustiawati et al., 2020; Sulaeman \& Fauziah, 2020). Membaca permulaan menekankan pada pengenalan huruf vocal, konsonan, dan diftong karena dilakukan dengan membaca nyaring dan lancar (bersuara). Membaca permulaan merupakan tahap awal dalam belajar membaca yang difokuskan kepada mengenal simbolsimbol atau tanda-tanda yang berkaitan dengan hurufhuruf sehingga menjadi pondasi agar siswa dapat melanjutkan ketahap membaca lanjut (Fauziah, 2019; Muslimin et al., 2014).

Kemampuan membaca merupakan bentuk kesanggupan siswa melakukan aktivitas kompleks baik fisik maupun mental, selain itu kemampuan membaca yang baik akan meningkatkan penguasaan dalam bidang akademik, serta berpartisipasi dalam kehidupan bermasyarakat. Dalam membaca hendaknya seseorang mempunyai tujuan, karena dengan memiliki suatu tujuan, cenderung lebih memaknai dan memahami suatu teks bacaan dibandingkan dengan orang yang tidak mempunyai tujuan.

Kegiatan membaca di kelas rendah sangat menentukan tingkat dan ketertarikan siswa dalam kegiatan membaca. Saat siswa merasa bahwa membaca adalah suatu kebutuhan maka pada proses pembelajaran selanjutnya siswa akan menjadikan membaca suatu kebiasaan yang sangat tinggi akibat dari kebiaasaan membaca membuat siswa memiliki wawasan dan informasi yang lebih luas dan bermakna,

\section{METODE PENELITIAN}

Penelitian yang penulis lakukan mengunakan pendekatan kuantitatif jenis eksperimen dengan rancangan Pretest Posttest Control Group Desain yaitu penulis membagi dua kelompok dimana satu kelompok belajar melalui aplikasi WhatApp dengan orang tua mereka bekerja sedangkan kelompok satu lagi orang tuanya tidak bekerja terhadap pengaruh atau efek suatu perlakuan diputuskan berdasarkan perbedaan antara pretest dengan 
postest. Tempat penelitian ini dilakukan di kelurahan Jatisampurna kota Bekasi. Waktu penelitian dilakukan semenjak November 2020 - Januari 2021. Penelitian dilakukan berdasarkan pengamatan yang telah penulis cermati semenjak Mei 2020 sampai masuknya tahun ajaran baru 2020/2021 saat dijadwalkan bahwa pengajaran tatap muka akan dilakukan pada semester 1 tahun pelajaran 2020/2021. Teknik pengumpulan data yang digunakan dalam pada penelitian ini, yaitu dengan cara tes, pengamatan (observasi), dan dokumentasi. Teknik pengumpulan data merupakan langkah yang paling strategis dalam mendapatkan data dalam bentuk responden (Margono, 2010; Sugiyono, 2015).

Hipotesis penelitian untuk mengetahui apakah yang diajukan diterima atau ditolak. Pengujian yang digunakan, yaitu pengujian korelasi uji-t dilakukan untuk mengetahui ada atau tidaknya pengaruh pengunaan aplikasi WA terhadap kemampuan membaca permulaan pada siswa yang bekerja dan orang tua yang tidak bekerja, yaitu prestasi belajar kelompok eksperimen dan kelompok kontrol yang dianalisis menggunakan statistik dengan taraf signifikan $\alpha=0,05$. Independent Sempel Test atau uji beda rata-rata yang digunakan untuk menguji dua rata-rata dari dua kelompok yang independen.

\section{HASIL DAN PEMBAHASAN}

Selama proses penelitian yang penulis lakukan di kelurahan Jatisampurna kota Bekasi sample penelitian penulis peroleh dari beberapa anak yang telah terdaftar di sekolah swasta maupun negeri yang berada di lingkungan tempat tinggal penulis. Penulis memperoleh beberapa informasi tentang gambaran pengajaran yang mereka jalani dari orang tua, guru, dan siswa.

Berdasarkan hasil normalitas dan homogenitas menunjukkan bahwa data yang diperoleh berdistribusi normal dan kedua kelas eksperimen dan kontrol bersifat homogen atau memiliki varians yang sama besar. Uji normalitas menunjukkan bahwa nilai signifikan pretest pada kelompok eksperimen adalah 0,649 dan nilai signifikan pretest kelas kontrol adalah 0,844 . Hali ini membuktikan bahwa kedua kelas nilai baik dari kelas eksperimen maupun kelas kontrol lebih besar dari nilai alpha 0.05 . Karena nilai signifikan kedua kelas lebih besar dari nilai alpha $\alpha 0.05$ $(0,200>\alpha=0.05)$, maka data kedua kelas berdistribusi normal.

Tabel 1. Hasil Uji Normalitas Posttest Kelompok Eksperimen Dan Kelompok Kontrol

\begin{tabular}{c|l|r|r|r|r|r|r}
\multirow{3}{*}{ skor } & \multicolumn{3}{|c|}{ Kolmogorov-Smirnov } & \multicolumn{3}{c}{ Shappiro_Wilk } \\
\cline { 2 - 8 } & & ststistic & Df & Sig. & ststistic & Df & Sig. \\
\cline { 2 - 8 } & Posttes Eksperimen & .118 & 20 & $.200^{*}$ & .974 & 20 & .843 \\
\cline { 2 - 9 } & Posttest Kontrol & .171 & 20 & .130 & .885 & 20 & .022 \\
\hline
\end{tabular}

Hasil nilai signifikan posttest pada kelas eksperimen adalah 0,843 dan nilai signifikan posttest kelas kontrol adalah 0,022. Hal ini membuktikan bahwa kedua nilai baik dari kelas eksperimen maupun kelas kontrol lebih besar dari nilai alpha 0.05 . Karena nilai signifikan kedua kelas lebih besar dari nilai alpha $\quad \alpha \quad 0.05 \quad(0.200>\alpha=0.05 \quad$ dan $0.130>\alpha=0.05)$, maka data kedua kelas berdistribusi normal. melakukan uji homogenitas. Hasil uji homogenitas menujukkan bahwa nilai probabilitas (signifikansi) adalah $0.006>\alpha=0.05$, maka Ho diterima. Hal ini membuktikan bahwa kedua sampel dari kelas eksperimen dan kelas kontrol berasal dari kelas homogen. 
Tabel 2. Hasil Uji Homogenitas Posttest Kelompok Eksperimen Dan Kelompok Kontrol

\begin{tabular}{l|r|r|r|r}
\hline & Levene Statistic & \multicolumn{1}{|c|}{ df1 } & df2 & \multicolumn{1}{c}{ Sig. } \\
\hline Based on mean & 6.616 & 1 & 38 & .014 \\
\hline Based on median & 6.568 & 1 & 38 & .014 \\
\hline $\begin{array}{l}\text { Based on median and with } \\
\text { adjusted df }\end{array}$ & 6.568 & 1 & 26.056 & .017 \\
\hline Based on trimmed mean & & & & 38 \\
\hline
\end{tabular}

Tabel di atas, menunjukkan bahwa nilai probabilitas (signifikansi) adalah $0.012>$ $\alpha=0.05$, maka Ho diterima. Hal ini membuktikan bahwa kedua sampel dari kelompok eksperimen dan kelompok kontrol berasal dari kelompok yang homogen. Disimpulkan kelompok sampel baik pretest mau posttest memiliki probabilitas > 0.05, artinya varian dari kedua sampel tersebut dinyatakan homogen.
Selanjutnya dapat dilakukan pengujian hipotesis dengan menggunakan bantuan SPSS versi 22.00. Uji Hipotesis data posttest kelas eksperimen dan kelas kontrol adalah untuk mengetahui pengaruh aplikasi whatsapp terhadap kemampuan membaca permulaan siswa kelas 1 sekolah dasar. Hasil perhitungan uji hipotesis dapat disajikan pada tabel berikut:

Tabel 3. Hasil Uji Hipotesis Kelompok Eksperimen dan Kelompok Kontrol Independent Samples Test

\begin{tabular}{|c|c|c|c|c|c|c|}
\hline \multirow{4}{*}{ skor } & & \multicolumn{2}{|c|}{$\begin{array}{l}\text { Levene's Test for Equality of } \\
\text { Variances }\end{array}$} & & & \\
\hline & & $\mathrm{F}$ & Sig. & $\mathrm{t}$ & df & $\begin{array}{l}\text { Sig. (2- } \\
\text { tailed) }\end{array}$ \\
\hline & Equal variances assumed & .005 & .945 & 7.199 & 38 & .000 \\
\hline & Equal variances not assumed & & & 7.199 & 37.825 & .000 \\
\hline
\end{tabular}

Berdasarkan tabel di atas, menunjukkan bahwa nilai probabilitas (signifikansi) adalah 0.000 . Karena nilai signifikansi $0.000<\alpha=0.05$, maka $\mathrm{H}_{0}$ ditolak. Hal ini membuktikan bahwa terdapat pengaruh pengajaran aplikasi whatsapp terhadap kemampuan membaca permulaan siswa kelas 1 sekolah dasar.

\section{Pembahasan}

Penelitian yang dilaksanakan pada siswa kelas I SD. Berdasarkan penelitian yang dilakukan peneliti melihat dan menemukan bahwa aplikasi whatsapp merupakan media pembelajaran yang digunakan pada masa pandemi. Aplikasi whatsapp dikatakan memiliki pengaruh terhadap kemampuan membaca permulaan. Pengunaan media pada masa pandemi merupakan alternative pembelajaran yang tepat untuk tetap berjalan. Pengunaan aplikasi whatsapp secara langsung memberikan pengaruh terhadap kemampuan membaca permulaan karena pembelajaran membaca permulaan yang harus dituntaskan guru pada kelas rendah menjadi kurang efektif.

Berdasarkan temuan yang peneliti peroleh pengaruh pengajaran dengan aplikasi whatsapp terhadap kemampuan membaca permulaan siswa kelas I yang diterapkan. Perolehan data dilapangan sebagaimana tes awal siswa dan tes akhirnya tidak memiliki perbedaan yang signifikan. Berdasarkan tes uji coba yang dilakukan pada anak yang orang tuanya bekerja dan tidak bekerja. Hasil uji coba siswa terhadap skor kemampuan membaca awal siswa tidak memiliki perbedaan yang signifikan dengan rata-rata siswa yang orang tuanya bekerja memperoleh rata-rata 
kemampuan membaca 72,53 dikarena sebagian anak mengikuti kelas informal sedangkan untuk siswa yang orang tunya tidak bekerja memperoleh rata-rata 85,97. Hal ini menunjukan tidak ada perbedaan antara siswa yang orang tuanya bekerja dengan siswa yang orang tunya tidak bekerja pada tes awal kemampuan membaca permulaan.

Berdasarkan hasil perhitungan uji hipotesis menunjukkan bahwa nilai probabilitas (signifikasi) adalah 0.000 . Karena nilai signifikansi $0.000<\alpha=0.05$, maka Ho ditolak, nilai tersebut membuktikan bahwa terdapat pengaruh pengajaran aplikasi whatsaap terhadap kemampuan membaca permulaan siswa kelas 1 di sekolah dasar.

Hasil analisis terhadap skor akhir siswa pengajaran aplikasi whatsapp siswa selama masa pandemic covid19 ditemukan perbedaan rata-rata tes kemampuan membaca siswa, yang orang tuanya bekerja karena WFH (work from home) mendampingi anaknya belajar di rumah memperoleh nilai rata-rata kemampuan membaca 72,53. Selanjutnya orang tua yang tidak bekerja justru memperoleh nilai rata-rata 85,97 sama dengan nilai awal.

Hasil penelitian diatas diperkuat dengan penelitian sebelumnya yang dilakukan oleh Widhiyasari (2019), Edi Suryadi (2018) yang menyatakan bahwa pemanfaatan media whatsapp dalam proses pebelajaran diantaranya disiplin dan keaktifan belajar siswa memiliki pengaruh yang signifikan.

\section{SIMPULAN DAN REKOMENDASI}

Simpulan penelitian ini menjelaskan bahwa pengajaran selama pandemi covid-19 untuk siswa kelas 1 tidak efektif mengunakan aplikasi Whatsapp sebagai media atau alat belajar khususnya membaca. Pengajaran membaca permulaan mengunakan aplikasi whatsaap bagi guru, orang tua dan siswa sangat tidak efektif karena untuk orang tua harus bekerja dan berada.

Nilai rata-rata akhir kelas eksperimen
85.97 lebih tinggi dibandingkan dengan nilai akhir kelas kontrol sebesar 72.53. Berdasarkan hasil perhitungan uji hipotesis menunjukkan bahwa nilai probabilitas (signifikasi) adalah 0.000 . Karena nilai signifikansi $0.000<\alpha=$ 0.05, maka Ho ditolak, artinya hal ini membuktikan bahwa terdapat pengaruh pengajaran aplikasi whatsapp terhadap kemampuan membaca siswa kelas 1 sekolah dasar.

\section{DAFTAR PUSTAKA}

Chandra, C., Mayarnimar, M., \& Habibi, M. (2018). Keterampilan Membaca Dan Menulis Permulaan Menggunakan Model Vark Untuk Siswa Sekolah Dasar. Jurnal Inovasi Pendidikan Dan Pembelajaran Sekolah Dasa, 2(1).

Dewi, S. M., Hasanah, S., \& Kusumah, D. (2021). The Effect Of Problem-Based Learning ( $\mathrm{Pbl}$ ) Model On The ProblemSolving Skills In Social Science In Elementary School Pengaruh Model Pembelajaran Problem Based Learning ( $\mathrm{Pbl}$ ) Terhadap Kemampuan Memecahkan Masalah Dalam Primary: Jurnal Pendidikan Guru. 10, 134-143.

Elianur, C. (2017). Pemanfaatan Aplikasi Whatsapp Sebagai Sarana Diskusi Antara Pengawas Dan Guru Pendidikan Agama Islam. Jurnal As-Salam, 1(2), 1-14.

Fauziah, M. (2019). Meningkatkan Keterampilan Membaca Intensif Melalui Metode Group Investigation Di Kelas Iiib Sdn 05 Vi Suku. Jurnal Pendidikan Dan Penelitian, 2(2), 169-175.

Gustiawati, R., Arief, D., \& Zikri, A. (2020). Pengembangan Bahan Ajar Membaca Permulaan dengan Menggunakan Cerita Fabel pada Siswa Sekolah Dasar. Jurnal Basicedu, 4(2), 355-360. https://doi.org/10.31004/basicedu.v4i2.33 9

Margono. (2010). Metodologi Penelitian Pendidikan. Rineka Cipta.

Muslimin, M., Tahir, M., \& Patekkai, I. 
(2014). Peningkatan Kemampuan Membaca Permulaan Siswa Kelas I MIS Sinoutu Melalui Metode Struktural Analitik Sintetik (SAS). Jurnal Kreatif Tadulako Online, 2(1), 155-167. http://jurnal.untad.ac.id/jurnal/index.php/ JKTO/article/view/3002

Rifki, F. (2017). Perubahan Budaya Komunikasi Pada Pengguna Whatsapp Di Era Media Baru. JIKE, 1(1), 1-10.

Setiati, S., \& Azwar, M. K. (2020). COVID-19 and Indonesia. Acta Med Indones Indones J Intern Med, 52(1), 84-89.

Sugiyono. (2015). Metode Penelitian Kuantitatif Kualitatif dan R\&D. Alfabeta. Sulaeman, Y., \& Fauziah, M. (2020). Efektifitas Metode Scrambel Dalam Meningkatkan Kemampuan Membaca Nyaring Pada Siswa Kelas Ii Sekolah Dasar. Jurnal Pajar (Pendidikan Dan Pengajaran), 4(6), 1251-1258.

Suryadi, E., Ginanjar, M. H., \& Priyatna, M. (2018). Penggunaan Sosial Media Whatsapp Pengaruhnya Terhadap Disiplin Belajar Peserta Didik Pada Mata Pelajaran Pendidikan Agama Islam (Studi Kasus Di Smk Analis Kimia Ykpi Bogor). Edukasi Islami: Jurnal Pendidikan Islam, 7(01), 1. https://doi.org/10.30868/ei.v7i01.211

Syarifhidayat, P. ., \& Hendra, W. (2018). Pemanfaatan aplikasi whatsapp (Wa) dikalangan Pelajar (Studi kasus Di Mts Almuddatsiriyah dan MTS Jakarta Pusat). Prosiding SNaPP2017 Sosial, Ekonomi, Dan Humaniora, 98-109.

Widhiyasari, M., Umami, N., \& Suja'I, I. S. (2019). Pengaruh Penggunaan Media Sosial Whatsapp Terhadap Keaktifan Siswa Pada Mata Pelajaran Ekonomi Bisnis Kelas X Smk Negeri 2 Boyolangu Tahun Ajaran 2018/2019. Jurnal
Pendidikan Ekonomi, 12(2), 94-98. 